\title{
The Role of Health Education in Promotion of Knowledge of Breast Self-Examination
}

\author{
Shaza Mohamed Alamin* \\ Khartoum North, Faculty of Public Health, AlzaimAlazhari University, Sudan
}

*Corresponding Author: Shaza Mohamed Alamin, Faculty of Public Health, AlzaimAlazhari University, Sudan.Email:awab222p@yahoo.com

\begin{abstract}
Breast cancer forms the highest percentage of cancer in Sudan (85\%). The importance of the study of breast cancer lies in the fact that early detection can maximize the benefits of intervention. One of the most important and simplest methods of early detection is self-examination, which can be conducted by the woman herself at home. This is Quasi-Experimental study to assess the role of health education in raising the awareness of university students in regard to the early detection of breast cancer (2011-2013).200 female students from third and fourth class faculties of law and economics, Al Zaem Al Azhari University were selected randomly, randomization had selected law students as study group, while Economics students were left as control group. Data had been collected from both students using a questionnaire, specifically designed to serve this purpose. Information collected with the official personnel from both federal and state ministry of health was done beside the Non Governmental Orgnaizition (NGOs) that are active in the same field. Interventions were conducted to the study group to raise the awareness of the students through lectures, video shows, distribution of pamphlets and practical demonstration of self-examination of the breast using manikin. Post intervention data was collected from both groups and analyzed using SPSS computer program. Results revealed that knowledge of breast cancer among students of law and Economics respectively was ranging between (68\%-86\%), knowledge of breast self examination (38\% -43\%) and those who thought breast cancer is difficult to be detected early were (68\%-63\%). Students practicing self-examination of the breast were $(22 \%-13 \%)$, those who were interested to join a training program in are $(85 \%-67 \%)$. After intervention, results changed with high significant rate among the study group. Knowledge about breast cancer extended to (100\%).Knowledge about breast self examination $(90)(P=0.00 \%)$, knowledge of how to conduct breast self-examination was $(50 \%)(P=0.025)$. Changing in attitude toward detected early were $(77 \%)(P=$ $.031)$. Those who were interested to join a training program in the future were $(50 \%)(P=0.003)$. This study concluded that: knowledge of breast cancer among the study group and control group was high. More than half of the students in both groups do not know how to perform the test, but after intervention this dropped among the study group to (10\%) while a minimal change has been noticed in the control group. More than $(50 \%)$ of the students in both groups showed a positive attitude towards participation in a training educational program of breast cancer. The study recommended that strengthening the health education program of breast cancer and breast self examination in universities and high school, and training of the students on how conduct the breast self examination, collaboration with the student social ties, utilize mass media to raise the awareness of women and the community as a whole with breast cancer and its early detection. With collaboration with civil organization
\end{abstract}

Justification: The central region of Sudan comprises four states including Blue Nile, al-Gezira, Sennar, and White Nile. Each of these states has a population ranging from 600,000 to 3,797,000.The majority of the population lives in the Capital regions and the rest in surrounding rural areas. Breast self-examination is one of the effective screening measures and has been proven to be effective in discovering lumps at an early stage It is a free, private, relatively simple examination and is a useful measure when mammography screening is not available, especially in the rural and poor inner urban areas(6).

This conform the reason behind conducting this study to serve this purpose and to tell every woman that breast cancer is detectable and curable in its early stage.

Keywords: the role of health education in promotion of knowledge of breast self-examination. To assess the knowledge of respondents towards breast self-examination.To conducts and assesses the health education increasing the early detection to promote breast self-examination 


\section{INTRODUCTION}

Breast cancer is by far the most frequent cancer of women and is a major public health problem in many developed and developing countries. In addition to being a life threatening disease, it has a major impact on women's quality of life and on society at large in terms of economic burden, such as reduced productivity and premature death. The average 5-year survival for breast cancer in developed countries is $73 \%$ and in developing countries is 57\%. Ageadjusted breast cancer death rates have declined in the developed countries, due to screening and early detection practices. Unfortunately, public and professional knowledge, attitudes and practice (KAP) that have helped control cancer in developed countries are often not readily available in developing countries. (1)

Breast self-examination (BSE) provides a relatively simple, low cost method of early detection that can be performed more frequently than mammography or clinical breast examination. Monthly BSE has been reported to be effective in detecting the early symptoms of breast cancer which, in turn, greatly reduces mortality from breast cancer. However, despite the risk of breast cancer and the efficacy of monthly BSE many women do not perform BSE on a regular basis, even those with a family history of breast cancer (1)Measures to reduce the stage at diagnosis are likely to have the greatest overall benefit in terms of both survival and costs. There is considerable indirect evidence from studies that clinical breast examination (CBE) can be recommended as a method for detecting breast cancer for public health benefit. It is easy to perform, is inexpensive and it can be readily taught to health care providers. CBE should be part of any program for early detection of breast cancer worldwide, provided that follow-up medical and oncology care is available (2)

\section{Methodology}

\subsection{Study Design}

The study was a quasi-experimental interventional study

\subsubsection{Study Areas and Study Setting}

Al Zaem Al Azhari University AAU-Sudan, Faculty of Sharia and Law and faculty of Economics and Administration were selected as the study setting.

\subsubsection{Study Population}

$3^{\text {rd }}$ and $4^{\text {th }}$ years Female Students of both Faculties of Sharia and Law and faculty of Economics and Administration.

\subsubsection{Sampling Techniques}

Randomly the Faculty of Sharia and Law was selected for the intervention, while the Faculty of Economics and Administration was left as the control. Simple random sampling was used for student's attendance sheet and then selected randomly according to the sample size by using random digit table through the computer, (100) students were allotted for each faculty.

\subsection{Data Collection}

A structured questionnaire was designed for the study. It was pretested in (10) students to retest the questionnaire if it clear or not. Minor amendment was introduced as result of pretest. The same questionnaire was use in the pre and posttest. The same questionnaire was distributed to the two intervention and control croups. Intervention was conducted in the study croup, while control croup was left intact.

\subsubsection{Information Collection from Key Personnel}

Key personnel's from both federal and state ministries of health were met and reports concerning breast cancer were collected. Data collect by meeting them.

\subsubsection{Intervention}

First step: I distributed a pre questionnaire to the (100) participants which covers knowledge, attitude and practices towards breast cancer and breast self-examination. Second step the participants were divided into two equal groups, each group received lectures using Power Point. lectures covered the breast cancer and its causes, how to perform proper breast self-examination and this was supported by a video tape. At the end of the lectures the groups raised different questions especially ones concerning factors that may lead to breast cancer and the behavior that may contribute to it. Demonstration of breast self-examination was done by using especial manikin for that purpose. Then participants have started to practice the breast self-examination by themselves. At the end two kinds of pamphlets were distributed to the participants covering the different types of breast cancer, factors contributing to it and how to perform proper breast self-examination. This intervention was 
conducted in collaboration with women initiatives organization. This intervention spent three months.

\subsubsection{Post-test}

After intervention both groups were given three month break (memory gap), then the questionnaire was administered to both of them.

\subsection{Data Analysis And Presentation}

Data was analyzed by using Statistical Package for the Social Sciences (SPSS) statistical package for social sciences and was presented in tables and figures. Correlation tests were also used to detect relation between variables.

\subsection{Ethical Considerations}

The required permission from the two faculties was obtained in writing. The target students consent was obtained verbally, having been well briefed on the purpose of the study. All students participated.

\section{Results}

All the flowing figures and tables show the result of the students in the faculty of law (study group) and faculty of economics and administration (control group) in Alzaeim Al Azhari University-2013.

Table1. Comparison of Control Group (pre - post) and Intervention Group (pre - post), Knowledge about Breast Cancer,Alzaeim Al Azhari University-2013

\begin{tabular}{|c|c|c|c|c|c|c|c|c|}
\hline \multirow[t]{3}{*}{ Knowledge } & \multicolumn{4}{|c|}{$\begin{array}{l}\text { Control group } \\
(\mathrm{N}=100)\end{array}$} & \multicolumn{4}{|c|}{$\begin{array}{l}\text { Intervention group } \\
(\mathrm{N}=\mathbf{1 0 0})\end{array}$} \\
\hline & \multicolumn{2}{|l|}{ Pre } & \multicolumn{2}{|c|}{ Post } & \multicolumn{2}{|l|}{ Pre } & \multicolumn{2}{|c|}{ Post } \\
\hline & No & $\%$ & No & $\%$ & No & $\%$ & No & $\%$ \\
\hline Yes & 86 & 86 & 90 & 96.8 & 68 & 68 & 100 & 100 \\
\hline No & 14 & 14 & 3 & 3.2 & 32 & 32 & 0 & 0 \\
\hline Total & 100 & 100 & 93 & 100 & 100 & 100 & 100 & 100 \\
\hline Test & \multicolumn{4}{|c|}{$\begin{array}{l}\text { Chi-Square }=6.964 \\
\text { P. value }=0.008\end{array}$} & \multicolumn{4}{|c|}{$\begin{array}{l}\text { Chi-Square }=38.095 \\
\text { P. value }=0.000\end{array}$} \\
\hline
\end{tabular}

As shown in table (1) there was a highly significant $(\mathrm{P}=.000)$ improvement in knowledge about breast cancer of the

Table2. Comparison of Control Group (pre - post) and Intervention Group (pre-post), Knowledge about signs of Breast Cancer. Alzaeim Al Azhari University-2013

\begin{tabular}{|l|l|l|l|l|l|l|l|l|}
\hline \multirow{2}{*}{ Knowledge } & \multicolumn{3}{|c|}{$\begin{array}{c}\text { Control group } \\
\text { (N=86) }\end{array}$} & \multicolumn{4}{c|}{$\begin{array}{c}\text { Intervention group } \\
\text { (N=68) }\end{array}$} \\
\cline { 2 - 10 } & Pre & Post & Pre & \multicolumn{3}{c|}{ Post } \\
\cline { 2 - 10 } & No & $\%$ & No & $\%$ & No & $\%$ & No & $\%$ \\
\hline Lump in the breast & 58 & 67.4 & 55 & 61.1 & 47 & 69.1 & 50 & 50 \\
\hline Redness and ulceration of the breast & 16 & 18.6 & 13 & 14.4 & 13 & 19.1 & 33 & 19.6 \\
\hline Nipple discharge & 8 & 9.3 & 12 & 13.3 & 8 & 11.8 & 17 & 17 \\
\hline All above & 2 & 2.3 & 7 & 7.8 & 0 & 0 & 13 & 13 \\
\hline Others & 2 & 2.3 & 3 & 33 & 0 & 0 & 0 & 0 \\
\hline Total & 86 & 100 & 90 & 100 & 68 & 100 & 100 & 100 \\
\hline & Chi-Square $=4.079$ & & $\begin{array}{l}\text { Chi-Square }=12.164 \\
\text { P. value }=0.007\end{array}$ \\
\hline
\end{tabular}

Table (2) shows that, there is no significant significant difference $(\mathrm{P}=0.007)$ intervention difference in Knowledge about breast cancer group.

definition in control group. But a highly

Table3. Comparison of Control Group (pre - post) and Intervention Group (pre-post), Knowledge about Type of Symptoms of Breast Cancer. Alzaeim Al AzhariUniversity-2013

\begin{tabular}{|l|l|l|l|l|l|l|l|l|}
\hline \multirow{4}{*}{ Knowledge } & \multicolumn{4}{|c|}{$\begin{array}{c}\text { Control group } \\
\text { (N=11) }\end{array}$} & \multicolumn{5}{c|}{$\begin{array}{c}\text { Intervention group } \\
\text { (N=43) }\end{array}$} \\
\cline { 2 - 11 } & Pre & Post & Pre & \multicolumn{3}{c|}{ Post } \\
\cline { 2 - 10 } & No & $\%$ & No & $\%$ & No & $\%$ & No & $\%$ \\
\hline high grade fever & 2 & 18.2 & 5 & 35.3 & 30 & 69.8 & 12 & 15 \\
\hline fatigue, exhaustion and nausea & 2 & 18.2 & 7 & 41.2 & 3 & 7 & 23 & 28.8 \\
\hline abnormal swelling of the breast & 4 & 35.4 & 3 & 17.5 & 10 & 23.3 & 23 & 28.8 \\
\hline Others & 3 & 27.3 & 1 & 5.9 & 0 & 0 & 0 & 0 \\
\hline All above & 0 & 0 & 0 & 0 & 0 & 0 & 22 & 27.6 \\
\hline
\end{tabular}




\begin{tabular}{|l|l|l|l|l|l|l|l|l|}
\hline \multicolumn{1}{|c|}{11} & 100 & 17 & 100 & 43 & 100 & 80 & 100 \\
\hline & 11 & \multicolumn{6}{c|}{$\begin{array}{c}\text { Chi-Square }=42.979 \\
\text { P. value }=.000\end{array}$} \\
\hline
\end{tabular}

Table (3) shows that, there is no significant difference in knowledge about type of symptoms of breast cancer, in control study (pre and post $) \quad(P$ value $=0.182)$, but a highly significant difference $(\mathrm{P}=.000)$ in intervention group.
Table (4), knowledge about risk factors in both control groups pre and post. Only 50 participants from pre and 55 participants know the risk factor of breast cancer (not significant difference, $\mathrm{P} .=0.203$ ), and increase knowledge about risk factors in intervention group (significant, P. = 0.000).

Table5. Comparison of Control Group (pre - post) and Intervention Group (pre - post), Knowledge about Types of Risk Factors of Breast Cancer. Alzaeim Al Azhari University-2013 (this related for only ask yes for previous question)

\begin{tabular}{|c|c|c|c|c|c|c|c|c|}
\hline \multirow[t]{3}{*}{ Know } & \multicolumn{4}{|c|}{$\begin{array}{c}\text { Control group } \\
(\mathbf{N}=\mathbf{5 0})\end{array}$} & \multicolumn{4}{|c|}{$\begin{array}{c}\text { Intervention group } \\
(\mathrm{N}=46)\end{array}$} \\
\hline & \multicolumn{2}{|l|}{ Pre } & \multicolumn{2}{|c|}{ Post } & \multicolumn{2}{|l|}{ Pre } & \multicolumn{2}{|c|}{ Post } \\
\hline & No & $\%$ & No & $\%$ & No & $\%$ & No & $\%$ \\
\hline Hereditary & 19 & 38 & 15 & 27.3 & 16 & 34.8 & 4 & 15 \\
\hline trauma or injury to the breast & 11 & 22 & 15 & 27.3 & 3 & 6.5 & 3 & 3.4 \\
\hline late marriage & 2 & 4 & 3 & 5.5 & 6 & 13 & 3 & 3.4 \\
\hline age above 40 & 0 & 0 & 6 & 10.9 & 7 & 15.2 & 2 & 2.3 \\
\hline exposure to radiation & 5 & 10 & 6 & 10.9 & 14 & 30.4 & 2 & 2.3 \\
\hline presence of a previous swelling in the breast 1 & 13 & 26 & 10 & 18.2 & 0 & 0 & 10 & 11.5 \\
\hline $\begin{array}{l}\text { Hereditary and age and exposure to } \\
\text { radiation }\end{array}$ & & 0 & 0 & 0 & 0 & 0 & 50 & 57.5 \\
\hline All above & 0 & 0 & 0 & 0 & 0 & 0 & 12 & 13.8 \\
\hline \multirow[t]{2}{*}{ Total } & 50 & 100 & 55 & 100 & 46 & 100 & 87 & 100 \\
\hline & \multicolumn{4}{|c|}{$\begin{array}{l}\text { Chi-Square }=7.547 \\
\text { P. value }=0.183\end{array}$} & \multicolumn{4}{|c|}{$\begin{array}{l}\text { Chi-Square }=87.828 \\
\text { P. value }=0.000\end{array}$} \\
\hline
\end{tabular}

Table (5) increase in the percentage of correct $(P$. value $=0.000)$, while no significant change answer for the question about risk factor of in control groups.

breast cancer in intervention group is significant

Table6. Comparison of Control Group (pre - post) and Intervention Group (pre-post), Knowledge of Methods of Early Detection of Breast Cancer. Alzaeim Al Azhari University-2013

\begin{tabular}{|c|c|c|c|c|c|c|c|c|}
\hline \multirow[t]{3}{*}{ Type Methods } & \multicolumn{4}{|c|}{$\begin{array}{c}\text { Control group } \\
(\mathrm{N}=68)\end{array}$} & \multicolumn{4}{|c|}{$\begin{array}{c}\text { Intervention group } \\
(\mathbf{N}=100)\end{array}$} \\
\hline & \multicolumn{2}{|l|}{ Pre } & \multicolumn{2}{|c|}{ Post } & \multicolumn{2}{|l|}{ Pre } & \multicolumn{2}{|c|}{ Post } \\
\hline & No & $\%$ & No & $\%$ & No & $\%$ & No & $\%$ \\
\hline Radiology & 30 & 44.1 & 25 & 35.7 & 13 & 21 & 10 & 10 \\
\hline examination by medical personnel & 27 & 39.7 & 23 & 32.9 & 21 & 33.9 & 30 & 30 \\
\hline breast self-examination & 9 & 13.2 & 14 & 20 & 19 & 30.6 & 23 & 23 \\
\hline radiology and examination by medical & 2 & 2.9 & 6 & 8.6 & 6 & 9.7 & 7 & 7 \\
\hline all above & 0 & 0 & 2 & 2.9 & 3 & 4.8 & 30 & 30 \\
\hline \multirow{2}{*}{ Total } & 68 & 100 & 70 & 100 & 62 & 100 & 100 & 100 \\
\hline & \multicolumn{4}{|c|}{$\begin{array}{l}\text { Chi-Square }=5.834 \\
\text { P. value }=0.212\end{array}$} & \multicolumn{4}{|c|}{$\begin{array}{l}\text { Chi-Square }=16.524 \\
P . \text { value }=0.002\end{array}$} \\
\hline
\end{tabular}

As shown in table (6) there was no significant difference (P. $=0.212)$, in knowledge about type methods of early detection of breast cancer

\begin{tabular}{|c|c|c|c|c|c|c|c|c|}
\hline \multirow[t]{3}{*}{ Knowledge } & \multicolumn{4}{|c|}{$\begin{array}{c}\text { Control group } \\
(\mathrm{N}=100)\end{array}$} & \multicolumn{4}{|c|}{$\begin{array}{c}\text { Intervention group } \\
(\mathbf{N}=100)\end{array}$} \\
\hline & \multicolumn{2}{|l|}{ Pre } & \multicolumn{2}{|c|}{ Post } & \multicolumn{2}{|l|}{ Pre } & \multicolumn{2}{|c|}{ Post } \\
\hline & No & $\%$ & No & $\%$ & No & $\%$ & No & $\%$ \\
\hline Yes & 43 & 43 & 50 & 53.8 & 38 & 38 & 90 & 90 \\
\hline No & 57 & 57 & 43 & 46.2 & 62 & 62 & 10 & 10 \\
\hline \multirow[t]{2}{*}{ Total } & 100 & 100 & 93 & 100 & 100 & 100 & 100 & 100 \\
\hline & \multicolumn{4}{|c|}{$\begin{array}{c}\text { Chi-Square }=2.236 \\
\text { P. value }=0.135\end{array}$} & \multicolumn{4}{|c|}{$\begin{array}{l}\text { Chi-Square }=58.681 \\
\text { P. value }=0.000\end{array}$} \\
\hline
\end{tabular}


As shown in table (7) no significant difference $(\mathrm{P}=0.135)$ in knowledge about (B.S.E )breast self-examination in control group, but highly

Table8. Comparison of control group (pre - post) and Intervention group (pre - post), knowledge about meaning of breast self-examination. Alzaeim Al Azhari University-2013

\begin{tabular}{|l|l|l|l|l|l|l|l|l|}
\hline \multirow{2}{*}{ Knowledge } & \multicolumn{3}{|c|}{$\begin{array}{c}\text { Control group } \\
\text { (N=100) }\end{array}$} & \multicolumn{3}{c|}{$\begin{array}{c}\text { Intervention group } \\
\text { (N=100) }\end{array}$} \\
\cline { 2 - 9 } & Pre & Post & No & $\%$ & Pre & $\%$ & Nost & $\%$ \\
\cline { 2 - 9 } & No & 39.5 & 28 & 56 & 29 & 76.3 & 0 & 0 \\
\hline $\begin{array}{l}\text { An examination afemale } \\
\text { performs on herself }\end{array}$ & 17 & 55.8 & 19 & 38 & 9 & 23.7 & 0 & 0 \\
\hline $\begin{array}{l}\text { an examination afemale } \\
\text { performs with the } \\
\text { assistance }\end{array}$ & 24 & & & & & & \\
\hline Both & 2 & 4.7 & 3 & + & 0 & 0 & 90 & 100 \\
\hline Total & 100 & 100 & 93 & 100 & 38 & 100 & 90 & 100 \\
\hline & $\begin{array}{l}\text { Chi-Square }=2.960 \\
\text { P. value }=0.228\end{array}$ & $\begin{array}{l}\text { Chi-Square }=128.000 \\
\text { P. value }=0.000\end{array}$ \\
\hline
\end{tabular}

As shown in table (8) no significant difference ( $\mathrm{P}=0.228)$ in knowledge about meaning of

breast self-examination, but highly significant difference $(\mathrm{P}=0.000)$ in Intervention group

Table9. Comparison of Control Group (pre - post) and Intervention Group (pre - post), about the Right Position for Breast Self-examination. Alzaeim Al Azhari University-2013

\begin{tabular}{|c|c|c|c|c|c|c|c|c|}
\hline \multirow[t]{3}{*}{ Position } & \multicolumn{4}{|c|}{$\begin{array}{c}\text { Control group } \\
(\mathrm{N}=\mathbf{2 0})\end{array}$} & \multicolumn{4}{|c|}{$\begin{array}{c}\text { Intervention group } \\
(\mathbf{N}=\mathbf{5 0})\end{array}$} \\
\hline & \multicolumn{2}{|l|}{ Pre } & \multicolumn{2}{|c|}{ Post } & \multicolumn{2}{|l|}{ Pre } & \multicolumn{2}{|c|}{ Post } \\
\hline & No & $\%$ & No & $\%$ & No & $\%$ & No & $\%$ \\
\hline standing in front of mirror & 8 & 61.5 & 6 & 30 & 12 & 54.5 & 0 & 0 \\
\hline laying on the bed & 2 & 15.4 & 5 & 25 & 10 & 45.5 & 0 & 0 \\
\hline both position & 3 & 23.1 & 9 & 45 & 0 & 0 & 50 & 100 \\
\hline \multirow[t]{2}{*}{ Total } & 13 & 100 & 20 & 100 & 22 & 100 & 50 & 100 \\
\hline & \multicolumn{4}{|c|}{$\begin{array}{l}\text { Chi-Square }=3.232 \\
\text { P. value }=0.117\end{array}$} & \multicolumn{4}{|c|}{$\begin{array}{l}\text { Chi-Square }=72.000 \\
\mathrm{P} . \text { value }=0.000\end{array}$} \\
\hline
\end{tabular}

Table (9) shows that, there is no significant difference $(\mathrm{P}$ value $=0.117)$ about the right position for BS.E in control group, but highly

Table10. Comparison of Control Group (pre - post) and Intervention Group (pre - post), Best Time to Conduct Breast Self-examination. Alzaeim Al Azhari University-2013.

\begin{tabular}{|c|c|c|c|c|c|c|c|c|}
\hline \multirow[t]{3}{*}{ Best Time } & \multicolumn{4}{|c|}{$\begin{array}{l}\text { Control group } \\
(\mathrm{N}=20)\end{array}$} & \multicolumn{4}{|c|}{$\begin{array}{c}\text { Intervention group } \\
(\mathbf{N}=\mathbf{5 0})\end{array}$} \\
\hline & \multicolumn{2}{|l|}{ Pre } & \multicolumn{2}{|c|}{ Post } & \multicolumn{2}{|l|}{ Pre } & \multicolumn{2}{|c|}{ Post } \\
\hline & No & $\%$ & No & $\%$ & No & $\%$ & No & $\%$ \\
\hline during the menstrual & 5 & 38.5 & 7 & 35 & 5 & 22.7 & 0 & 0 \\
\hline before amenstrual cycle & 1 & 7.7 & 8 & 40 & 3 & 13.6 & 0 & 0 \\
\hline after amenstrual cycle & 7 & 53.8 & 5 & 25 & 14 & 63.6 & 50 & 100 \\
\hline \multirow[t]{2}{*}{ Total } & 13 & 100 & 20 & 100 & 22 & 100 & 50 & 100 \\
\hline & \multicolumn{4}{|c|}{$\begin{array}{l}\text { Chi-Square }=4.844 \\
\text { P. value }=0.089\end{array}$} & \multicolumn{4}{|c|}{$\begin{array}{l}\text { Chi-Square }=20.455 \\
\text { P. value }=0.000\end{array}$} \\
\hline
\end{tabular}

As shown in table (10) no significant B.S.E in control group, but highly significant difference $(\mathrm{P}=0.089)$ in best time to do the difference $(\mathrm{P}=0.000)$ in Intervention group.

Table11. Comparison of Control Group (pre - post) and Intervention Group (pre - post), Knowledge about the Symptoms and Signs to Look for when Performing the Examination. Alzaeim Al Azhari University-2013.

\begin{tabular}{|l|l|l|l|l|l|l|l|l|}
\hline \multicolumn{1}{|c|}{ Knowledge } & \multicolumn{3}{c|}{$\begin{array}{c}\text { Control group } \\
\text { (N=20) }\end{array}$} & \multicolumn{3}{c|}{$\begin{array}{c}\text { Intervention group } \\
(\mathbf{N}=50)\end{array}$} \\
\cline { 2 - 9 } & Pre & Post & Pre & \multicolumn{3}{c|}{ Post } \\
\cline { 2 - 9 } & No & $\%$ & No & $\%$ & No & $\%$ & No & $\%$ \\
\hline enlargement or change in the shape of the breast & 7 & 63.3 & 10 & 50 & 15 & 58.2 & 7 & 14 \\
\hline abnormal discharge from the nipple & 1 & 7.7 & 3 & 15 & 6 & 22.7 & 5 & 10 \\
\hline
\end{tabular}




\begin{tabular}{|l|l|l|l|l|l|l|l|l|}
\hline nipple retraction & 5 & 38.5 & 5 & 25 & 2 & 8.1 & 4 & 8 \\
\hline skin pitting or redness & 0 & 0 & 2 & 10 & 0 & 0 & 2 & 4 \\
\hline All above & 0 & 0 & 0 & 0 & 0 & 0 & 32 & 64 \\
\hline Total & 13 & 100 & 20 & 100 & 22 & 100 & 50 & 100 \\
\hline & \multicolumn{2}{|l|}{ Chi-Square $=2.141$} \\
& P. value $=0.544$ & & $\begin{array}{l}\text { Chi-Square }=31.442 \\
\text { P. value }=0.001\end{array}$ \\
\hline
\end{tabular}

The table (11) shows that there is no significant deference $(\mathrm{P}=0.544)$ in knowledge about the symptoms to look for when performing the examination in control group, but a highly significant difference $(\mathrm{P}=.001)$ in intervention group.

\section{DISCUSSION}

This was a quasi-experimental interventional study, aimed to assess the role of health education in promotion of knowledge, Attitudes and practices of breast selfexamination among female students. It conducted in the Faculty of Sharia and Law and the Faculty of Economics and Administration. The study covered (200) students. Since the number of students in the two faculties was very equal,(100) students were allotted for each school.

Randomly the faculty of sharia and law was selected for the intervention, while the faculty of economics and administration was left as the control. The data were collected by questionnaire and interview with key informants. The same questionnaire was use in the pre and posttest. The study found the following results:

Pre and posttest regarding knowledge of breast cancer among the study group was $(68 \% \& 100 \%)$ respectively with highly significant difference $(\mathrm{p}=\mathrm{o.001})$, while in the control group it was $(86 \%-96 \%)$ ( $p$ value $=.008$ ) and this resembles the study conducted in ElhajYousif area in (2004-2005) knowledge of breast cancer among higher secondary school teachers reached $(100 \%)^{(18)}$. which explains the high awareness of breast cancer as one of the most common cancers in women.

More than $60 \%$ of the students in both groups (study and control) didn't think that breast cancer can be detected early, this concept has changed dramatically after intervention to less than $30 \%$ among the study group with a significant difference ( $p$ value 0.031 )but it not change in control group (73\%) with( pvalue.173) also almost one third of both the study and the control groups couldn't realize that breast cancer is a curable disease but after the intervention this percentage had dropped to $(17 \%)$ with hilly significant difference (p value 0.o14) among the study group while no significant change had occurred among the control group ( $\mathrm{p}$ value 0.778) and this consolidate the old belief that cancer is incurable.

Concerning breast self-examination, it has been found that more than half of the students in both groups do not know how to perform the test, but after intervention this dropped among the study group with high significant difference $(p$ value 0.001 ) while a minimal change has been noticed in the control group in pre and post-test with ( ( $p$ value 0.135$)$, this is in line with the previous study conducted in 2005 at $\mathrm{U}$ of $\mathrm{K}^{(17)}$ although conducted among the most senior medical students but only $70 \%$ of them were familiar with the breast self-examination and this can be attributed to the belief among the majority of women that such examination is only performed by a physician.

Despite the public awareness of breast cancer, only $(25 \%)$ among the study group were able to identify two relevant risk factors and only (20\%) among the control group were able to do so, but in posttest a great progress was noticed among the study group with highly significant difference ( $p$ value 0.001 ), while no change was noticed among the control one ( $\mathrm{p}$ value 0.183 ). This was similar to the study conducted in university of Khartoum in $2005^{(17)}$, which revealed the half of the students (50\%) could not identify the causes related to breast cancer.

The pre-test revealed that more than $50 \%$ in both groups mentioned that TV was the only source of their knowledge concerning breast self-examination. Other sources were added in both groups in post-test to include friends, relatives, \& internet. These results were so close to the outcome of the studies conducted in both Nigeria ${ }^{(20)}$, Malaysia ${ }^{(23)} \&$ El Obeid $^{(19)}$ and this explains that the TV is the most common seen media besides the internet especially during the era of globalization.

\section{CONCLUSION}

The study concludes the following

Knowledge concerning breast cancer in both groups was good even without intervention but after intervention it increased. 
There was a dramatic change in the study group regarding knowledge of signs of breast cancer and early detection of breast cancer, while there was little change in the control group.

$>$ Mass media role alone is not effective, as both groups were exposed to its influence during the memory gap.

\section{RECOMMENDATIONS}

In order to control breast cancer so it will not become a major health problem anymore, the study recommends the following:-

a. Strengthening the health education program of breast cancer by conducting frequent health education sessions at the universities and high schools, collaborations with ministers of health.

b. Training of university students on how to conduct proper self-examination of the breast, collaboration with student social ties.

c. Provision of self-breast examination plus mammogram in the university, health centers.

d. Sending frequent messages through the radio and TV educating women about the importance of self-examination and its role in the early detection of breast cancer

e. Utilize mass media to raise the awareness of women and the community as a whole with breast cancer and its early detection.

f. Civil organization (NGO) can also assist in organizing programs involving women cancer early detection.

\section{REFERENCES}

[1] Wilson, C. M., Tobin S. Young, R. C: The Exploding Worldwide Cancer Burden: The Impact of Cancer on Women, International Journal of Gynecological Cancer,. 2004.

[2] Lori Jardines, MD, Bruce G. Haffty, MD, Paul Fisher, MD, Jeffrey Weitzel, MD, and Melanie Royce, MDBreast cancer overview-Risk Factors, Screening, Genetic Testing, and Prevention, PhD 2010

[3] Lori Jardines, MD, Bruce G. Haffty, MD, Paul Fisher, MD, Jeffrey Weitzel, MD, and Melanie Royce, MD, PhD Breast cancer overview - Risk factors, screening, genetictesting, and prevention-.2009

[4] Parkin, D. M., Bray, F., Ferlay, J., Pisani, P. Global Cancer Statistics,. CA:A Cancer Journal for Clinicians.2005
[5] Canadian Cancer Society. Breast cancer statistics available at: www.cancer.ca/Canada-. Accessed December, 2009

[6] Dr. AmalAbdelrahim Osman: Proposal of knowledge, attitude and practices (KAP) towards breast lumps among women in Khartoum state 2012.

[7] AshryGad Mohamed, Health education College of Medicine, KSU 2005

[8] Li Xiaohan. Health Education, School of Nursing-China Medical University, 2011

[9] WHO:Health promotion glossary. Geneva, accessed 23 March 2011

[10] U.S. Department of Health and Human Services, Office on Women's Health National Women's Health Information center,- August 2003

[11] Vetto, J. T., Petty, J. K., Dunn Structured Clinical Breast Examination Training Results in Objective Improvement in CBE Skills, Journal of Cancer Education, N., et al. (2002)

[12] The Biology of Breast Cancer, available at www.envirocancer. cornell.edu/Factsheet/General/fs5. biology.cfm

[13] International Agency for Research on Cancer (IARC), IARC Handbook on Cancer Prevention No. 7: Breast Cancer Screening. Lyon, France: IARC Press. 2002.

[14] Breast self-examination: A mixed message. J NatlCancer Inst.: Position Statement Updated September 2011

[15] Dr.MalleswarRaoKasina, Breast Self-Exam: MD,DG Special Grade Civil Surgeon, Dept. of ObGynecology, ESI Hospital,Hyderabad, AP, India 2006

[16] Schulz, K. D. Clinical Breast examination: What can be recommended for its use, International Electronic Journal of Health Education, Albert, U. S.,2003.

[17] Dr. Sit Al NesaAbdAlla Abdel HafeezAssessment of Breast Cancer Knowledge, Attitude and Screening Practices among Female University, a thesis submitted for partial fulfillment for MD community medicine University of Khartoum 2005,

[18] DrNagat Ahmed M. Elhassan Assessment of Knowledge, Attitudes, and Behavior towards Breast Self-Examination among Female Teachers at Secondary Schools. ElhajYousif Area in a thesis submitted for partial fulfillment for MD community medicine. 2005

[19] DrRashaBushra Ahmed: Study the Knowledge, Attitude and Practice of Female to Breast SelfExamination in ElObeid Teaching Hospital, a thesis submitted for partial fulfillment for MD community medicine 2008 
[20] F.O. Kayode, T. M. Akande, G.K. Osagmemi, Department of Epidemiology and Community Health, University of Ilorin, Nigeria,2005

[21] Lauren Wilson, Academy of Business andTechnology, Detroit, Michigan; University Health Center, Detroit, Michigan(2007)

[22] AminaKhatun, Dr. PiyanuchJittanoon, Dr. UmapornBoonyasopun, "The Relationship between Breast Self-Examination Efficacy and Breast Self-Examination Practice among Staff Nurses in Bangladesh". (Community Health Nursing), Faculty of Nursing, Prince of Songkla University 2010

[23] P. Parsa, M. Kandiah and N.Parsa: Factors Associated with Breast Self-Examination among Malaysian Women Teachers.2011

Citation: Shaza Mohamed Alamin. The Role of Health Education in Promotion of Knowledge of Breast SelfExamination. ARC Journal of Public Health and Community Medicine.2018; 3(1):26-33. DOI: dx.doi.org/ 10.20431/2456-0596.0301004.

Copyright: (C) 2018 Authors. This is an open-access article distributed under the terms of the Creative Commons Attribution License, which permits unrestricted use, distribution, and reproduction in any medium, provided the original author and source are credited. 